\title{
Le Pacifique en première ligne face au changement climatique. Présentation
}

\section{(2) OpenEdition \\ Journals}

Édition électronique

URL : https://journals.openedition.org/jso/11352

DOI : $10.4000 /$ jso. 11352

ISSN : $1760-7256$

Éditeur

Société des océanistes

Édition imprimée

Date de publication : 15 décembre 2019

ISBN : 978-2-85430-121-2

ISSN : 0300-953x

Référence électronique

"Le Pacifique en première ligne face au changement climatique. Présentation », Journal de la Société des Océanistes [En ligne], 149 | 2019, mis en ligne le 15 février 2020, consulté le 08 janvier 2022. URL : http://journals.openedition.org/jso/11352 ; DOI : https://doi.org/10.4000/jso.11352

Ce document a été généré automatiquement le 8 janvier 2022.

\section{(c) $(1) \odot$}

Journal de la société des océanistes est mis à disposition selon les termes de la Licence Creative Commons Attribution - Pas d'Utilisation Commerciale - Pas de Modification 4.0 International. 
Le Pacifique en première ligne face au changement climatique. Présentation 
1 Ce dossier thématique met en perspective les données et prévisions scientifiques, souvent inquiétantes, concernant les impacts socio-environnementaux du changement climatique dans le Pacifique Sud avec des travaux qui analysent comment les populations de cette région les appréhendent - à la fois en tant qu'ensemble de phénomènes physiques et en tant qu'ensemble de constructions discursives - et s'organisent pour y faire face. Les contributions originales rassemblées dans ce volume ne mettent pas seulement en lumière les connaissances et les interprétations liées aux changements rapides observés dans la région, ainsi que les divergences inévitables entre les perceptions des acteurs locaux et le discours scientifique dominant. Elles soulignent également l'émergence d'une réelle dynamique d'échange et de collaboration entre chercheurs, communautés et autres parties prenantes visant à définir et à mettre en œuvre diverses stratégies locales d'adaptation. Ce faisant, elles attirent l'attention sur les limites potentielles de ces coopérations, en particulier en termes d'échelles (spatiales et temporelles), d'efficacité, de durabilité et de sensibilité socioculturelle.

2 Par ailleurs, ce dossier thématique montre l'émergence progressive d'un positionnement stratégique commun des pays et territoires insulaires du Pacifique Sud qui, en dépit de niveaux d'exposition, d'expériences et d'attitudes très variables face au changement climatique, parlent désormais d'une voix globalement unifiée à la table des négociations internationales sur le climat. Finalement, nous espérons montrer que les sciences environnementales et sociales, à travers leurs approches distinctes et complémentaires, ont un rôle à jouer pour soutenir ces alliances, notamment en mettant en lumière la complexité et l'incertitude inhérentes aux «mondes du changement climatique » que tend trop souvent à masquer la présentation, certes captivante mais simpliste, des îles du Pacifique comme «en voie de disparition » et de leurs habitants comme en passe de devenir tous des « réfugiés climatiques ». 